\title{
WAKAF TUNAI BERBASIS CROWDFUNDING: PERSEPSI GENERASI Z \& Y
}

\author{
Hasanatul Ahwal ${ }^{1}$ \\ Universitas Airlangga \\ hasanatulahwal@gmail.com
}

\begin{abstract}
This study aims to look at the millennial perception of the existence of crowdfunding-based cash waqf as the dominant generation using technology services as well as to measure the effectiveness of the socialization of waqf that has been carried out, so that this perception can represent the potential of cash waqf in the future. This study uses 100 respondents consisting of academics in the field of Islamic economics, using PLS as a measuring tool that tests the suitability of the existing model in this study. The results of this study indicate that the religiosity factor is a factor that greatly influences generations $\mathrm{X}$ and $\mathrm{Z}$ in paying cash waqf, besides that the existence of fintech facilities in cash waqf payments is also considered very efficient.
\end{abstract}

\section{Keywords: Cash Waqf, Crowdfunding waqf, Generation $\mathrm{Y}$ and Z, Technology Acceptance Mdodel, Theory of Planned Behavior}

\begin{abstract}
ABSTRAK
Penelitian ini bertujuan untuk melihat persepsi para milenial terhadap adanya wakaf tunai berbasis crowdfunding sebagai generasi yang dominan menggunakan jasa teknologi juga mengukur efektifitas dari sosoialisasi wakaf yang sudah dilakukan, sehingga adanya persepsi tersebut dapat merepresentasikan potensi wakaf tunai di masa yang akan datang. Penelitian ini menggunakan 100 responden yang terdiri dari akademisi dibidang ekonomi Islam, dengan menggunakan PLS sebagai alat ukur yang menguji kecocokan model yang ada pada penelitian ini. Hasil penelitian ini menunjukkan bahwa faktor religiusitas menjadi faktor yang sangat mempengaruhi generasi $X$ dan $Z$ dalam menunaikan wakaf tunai, selain itu adanya fasilitas fintech dalam pembayaran wakaf tunai juga dinilai sangat efisien. Penelitian ini dapat digunakan sebagai tolak ukur pengetahuan masyarakat terkait wakaf khususnya wakaf tunai berbasis crowdfunding.
\end{abstract}

Kata Kunci: Wakaf Tunai, wakaf Crowdfunding, Generasi Y dan Z, Technology Acceptance Mdodel, Theory of Planned Behavior 


\section{PENDAHULUAN}

Wakaf merupakan suatu instrumen keuangan sosial Islam yang sifatnya berkelanjutan, dan didasarkan pada asas kerelaan para wakif. Wakaf ini bertujuan untuk membangun kesejahteraan umat, baik dalam bentuk pembangunan secara ekonomi maupun secara sosial (Sulaiman \& Alhaji Zakari 2019). Wakaf terdiri dalam berbagai jenis, diantaranya ialah wakaf tunai yang menjadi wakaf yang memiliki tingkat pengelolaan yang paling efisien.

Penggunaan wakaf tunai sebagai salah satu sumber dana publik baik dalam bentuk pembiayaan suatu proyek ataupun jasa telah diterapkan oleh beberapa negara. Indonesia sebagai negara dengan jumlah penduduk muslim terbesar juga memiliki potensi dalam mengembangkan jenis wakaf ini, potensi tersebut dapat dimanfaatkan untuk memenuhi kesenjangan sosial yang ada di masyarakat melalui maksimalisasi terhadap pengumpulan dana wakaf sebagai sumber pembiayaan (Shaikh et al 2017).

Dalam mengupayakan maksimalisasi potensi yang diharapkan tersebut, lembaga wakaf bekerjasama dengan lembaga pendidikan yang terdiri dari berbagai universitas untuk mensosialisasikan wakaf kepada masyarakat secara lebih luas. Hal ini diharapkan dapat memberikan perubahan terhadap pola pikir serta wawasan masyarakat akan keberadaan instrumen wakaf di Indonesia yang masih sangat minim. Oleh karena itu langkah ini sejalan dengan kendala utama yang dihadapi oleh lembaga perwakafan di Indonesia, dimana menurut BWI (Badan Wakaf Indonesia) tingkat pengetahuan masyarakat terkait wakaf dan mekanisme dari wakaf masih tergolong sangatrendah.

Sosialisasi yang dilakukan terutama kepada mahasiswa dapat memberikan dampak yang positif terhadap pengembangan wakaf tunai di Indonesia. Mahasiswa yang dikenal sebagai kaum milenial, merupakan generasi yang sudah memanfaatkan berbagai teknologi yang ada (Eastman et al 2014) dan rata-rata sudah menggunakan jasa fintech sebagai salah satu fasilitas dalam transaksi keuangan (Mcauley \& Weiner2015).

Salah satunya terkait dengan pengembangan dan pengumpulan wakaf tunai berbasis teknologi dalam bentuk crowdfunding. Penggunaan teknologi juga menjadi sarana yang mendukung upaya maksimalisasi wakaf tunai di masyarakat, dengan penyediaan layanan yang lebih mudah dan praktis (Ryu2018). Model ini sudah diterapkan oleh beberapa negara seperti halnya Malaysia yang menggunakan CWM (crowdfunding waqf model) untuk membiayai aset 
wakaf tanah yang rata-rata masih idle.

Penggunaan CWM ini berdampak positif terhadap pengumpulan dan pengembangan wakaf tunai di Malaysia (Thaker et al2018). Hal ini terkait dengan metode crowdfunding yang sejalan dengan perkembangan social networks communities yang ada di masyarakat (Mollick 2014).

Adanya teknologi crowdfunding berdasarkan fungsinya diasumsikan dapat menambah dan memperluas akses masyarakat dalam menunaikan wakaf tunai, oleh karena itu penggunaan metode crwodfunding akan diuji berdasarkan teori TAM dan TPB untuk mengetahui persepsi dan niat dari generasi milenial dalam penggunaan teknologi crowdfunding dalam pengumpulan wakaf tunai.

Penelitian ini mencoba melengkapi penelitian-penelitian sebelumnya dengan tidak hanya melihat dan mengukur potensi terhadap penggunaan crowdfunding dalam pembayaran wakaf tunai, akan tetapi juga bertujuan mengetahui persepsi dan penerimaan generasi milenial terhadap adanya fintech pada wakaf tunai, dilain sisi adanya penelitian ini juga dapat menggambarkan efektifitas sosialisasi yang telah dilakukan oleh BWI kepada masyarakat khususnya kepada para generasi Y dan Z melalui program "GOES TO CAMPUS".

\section{KERANGKA TEORI}

\section{Potensi dan Tantangan Pada Wakaf Tunai}

Wakaf tunai mulai populer digunakan oleh masyarakat seiring dengan populernya inovasi dan pengembangan wakaf saat ini, selain untuk mengimbangi perkembangan teknologi yang ada ditengah masyarakat saat ini, hal tersebut juga merupakan bagian dari upaya dalam mengatasi aset wakaf yang idle menjadi lebih produktif (Thoarlim et al 2017;Ismail et al 2014), sehingga upaya penggunaan dana dan asset wakaf yang ada dapat lebih maksimal dalam membantu meningkatkan kesejahteraan masyarakat (Che Hassan \& Rahman, 2018).

Namun terdapat beberapa kendala dalam hal pengelolaan wakaf tunai, umumya hal tersebut berkaitan dengan kualitas sumber daya manusia (nadzir) (Nurrachmi 2013), pendataan dan pelaporan (Khamis \& Che Mohd Salleh 2018; Kachkar 2017) serta tingkat pengetahuan dan kesadaran masyarakat terkait wakaf tunai (Fallis 2013).

H1: potensi pada wakaf tunai berpengaruh positif terhadap persepsi milenial dalam wakaf tunai 
berbasis crowdfunding

\section{Religiusitas}

Menurut Ashraf (2014) religiusitas merupakan suatu sikap yang menjadi representasi seseorang terhadap nilai-nilai agama yang dianutnya sehingga semua sikap, perilaku serta pola pikirnya sesuai dengan ajaran yang ada (Amaliah et al., 2015). Nilai religiusitas menjadi salah satu faktor mediasi (Alam et al., 2011) yang memberikan pengaruh terhadap pola adopsi dan konsumsi, salah satunya dalam memilih instrumen dan produk keuangan bagi masyarakat muslim (Eid \& El-Gohary 2015; Johan \& Putit 2016).

Menurut (Zamani-Farahani \& Musa, 2012) mengukur religiusitas dalam Islam dapat didasarkan pada iman dan pengimplikasiannya, sedangkan menurut Amaliah et al (2015) ada tiga faktor dalam konsep religiusitas menurut perspektif Islam yaitu keimanan, hukum shariah dan nilai moral, ketiga faktor tersebut dinilai dapat merepresentasikan nilai-nilai religiusitas dalam kehidupan masyarakat. Selain itu penggunaan varibel ini juga dinilai dapat mempengaruhi kontribusi masyarakat dalam menunaikan wakaf tunai (Rizal \& Amin 2017).

H2: Faktor religiusitas berpengaruh positif terhadap persepsi milenial dalam menggunakan crowdfunding berbasis wakaf tunai

\section{Crowdfunding}

Crowdfunding merupakan suatu sistem alternatif baru dari bidang keuangan yang terkait dengan pendanaan dalam bentuk platform online (Agreement \& Union 2020; Mollick 2014). Mohd Thas Thaker et al (2018) mengungakapkan bahwa crowdfunding merupakan salah satu metode pengumpulan dana, dalam jumlah yang relatif kecil untuk mendanai suatu proyek yang lebih besar besar melalui internet, tanpa menggunakan standar keuangan yang ada pada umumnya.

Hal tersebut dilakukan oleh beberapa investor untuk suatu proyek, baik yang untuk hal komersial maupun sosial (Mohd Thas Thaker et al 2018; Mollick 2014), karena selain dinilai lebih fleksibel metode crowdfunding juga lebih efisien untuk pengumpulan dana dengan jangka waktu yang relatif cepat dibandingkan instrumen keuangan lainnya (Agreement \& Union, 2020).

Mollick (2014) pada proyek yang menggunakan sistem crowdfunding umumnya berhasil menggumpulkan dana sebagai penambah modal atau pembiayaan suatu proyek, sehingga crowdfunding merupakan suatu metode pengumpulan dana yang berpotensi besar dalam 
memaksimalkan pengumpulan dana yang dilakukan. Umumnya aktifitas crowdfunding akan diposting diberbagai laman baik yang sifatnya privasi maupun situs yang dikhususkan untuk aktifitas tertentu yang ditujukan untuk penggalangan dana kepada masyarakat secara lebih luas (Rijanto 2018).

H3: Penggunaan crowdfunding berpengaruh positif terhadap peningkatan potensi wakaf tunai khususnya di kalangan milenial

\section{Technology AcceptenceModel}

Davis (1989) menggunakan teori TAM sebagai pengembangan dari teori TRA(Theory of Reasoned Action) yang dikhususkan untuk menganalisa adanya penerimaan dari pengguna teknologi yang didasarkan pada variabel persepsi penggunaan dan persepsi kemudahan yang dirasakan oleh pengguna. Menurut Davis (1989) teori ini efektif untuk menganilisa keputusan individu dalam menerima atau menolak suatu teknologi karena niat terhadap penggunaan teknologi secara langsung dapat dilihat dari perilaku penggunaan teknologi itu sendiri.

Oleh karena itu teori ini secara positif dapat digunakan sebagai tolak ukur penerimaan terhadap adopsi metode crowdfunding dalam pembayaran wakaf tunai. Beberapa peneliti menyarankan adanya penambahan faktor budaya ke dalam teori TAM, karena berdasarkan penelitian yang ada, budaya juga memberikan pengaruh terhadap keputusan individu dalam mengadopsi suatu teknologi (Akhtar et al 2019).

\section{Perceived Usefulness (Kegunaan Yang Dirasakan)}

Kegunaan dari penggunaan teknologi dapat diukur berdasarkan tingkat kepercayaan individu, bahwa dengan menggunakan suatu sistem tertentu dapat meningkatkan performa mereka, selain faktor ini juga dapat didefiniskan sebagai tingkat kepercayaan individu, bahwa penggunaan suatu sistem dapat membebaskan mereka dari beban tertentu baik dalam bentuk fisik maupun mental (F D Davis 1985).

\section{Perceived Ease To Use (Kemudahan Yang Dirasakan)}

Adanya kemudahan yang dirasakan menurut (F D Davis 1985) mempunyai pengaruh yang signifikan terhadap manfaat yang dirasakan oleh pengguna, karena upaya yang dikeluarkan menjadi lebih sedikit. Oleh karena itu dengan adanya kemudahan yang ditawarkan oleh suatu sistem, dapat memotivasi induvidu untuk menggunakan sistem tersebut (Zacharis2012). 
H4: Penggunaan crowdfunding berpengaruh positif terhadap efektifitas pembayaran wakaf tunai

H5: kemudahan crowdfunding berpengaruh positif terhadap fleksibelitas pembayaran wakaf tunai

\section{Technology Planned Behavior}

TPB merupakan pengembangan dari teori TRA (Theory of Reason Action) yang terdiri dari beberapa variabel pengukuran yakni sikap, norma subjektif, yang dikembangkan dengan manambahkan variabel kontrol perilaku (Collins et al 2011). Faktor utama dalam teori ini ialah niat atau kehendak individu terhadap suatu perilaku tertentu (Ajzen 1987).

Adanya suatu kehendak atau niat terhadap suatu perilaku dapat dijelaskan secara lebih akurat berdasarkan pengukuran terhadap prilaku, norma subyekif dan kontrol prilaku, dimana secara bersamaan kontrol perilaku serta niat dapat menggambarkan kesesuaian antara perilaku yang mendominasi serta keyakinan terhadap kontrol perilaku tersebut (Ajzen 2012). Sehingga penggunaan teori ini dapat menggambarkan dan memprediksi bagaimana prilaku dan sikap masyarakat terhadap adanya wakaf tunai berbasis crowdfunding (Ajzen 1991; Shneor \&Munim2019).

\section{Attitude Towards Behavior (Sikap Terhadap Perilaku)}

Merupakan sikap yang diperoleh dari evaluasi pada lingkungan sekitar, terkait positif atau negatifnya suatu perilaku (Ajzen 1991), hal tersebut dilakukan dengan cara mengevaluasi perilaku-perilaku tertentu sehingga individu akan mengetahui konskuensi dari manfaat ataupun kerugian yang akan diterima (Ramdhani 2016).

\section{Subjective Norm (Perilaku Subjektif)}

Perilaku ini menurut (Ajzen1991) berkaitan erat dengan tekanan sosial yang diterima oleh individu yang didasarkan pada persepsi lingkungan dan orang-orang sekitarnya, sehingga adanya dominasi penerimaan di masyarakat juga akan mempengaruhi keputusan individu.

\section{Perceived-Behavior Control (Kemudahan Atau Kesulitan Yang Dirasakan Dalam Melakukan Perilaku)}

Kontrol ini mengacu pada persepsi akibat dari suatu tindakan yang dirasakan oleh individu baik hal tersebut berasal dari lingkungan ataupun individu itu sendiri (Ajzen 1991) 
H6: Pengetahuan masyarakat dan persepsi lingkungan secara positif akan mempengaruhi pembayaran wakaf tunai berbasis crowdfunding

H7: Adanya tren teknologi berpengaruh positif terhadap penggunaan crowdfunding dalam pembayaran wakaf tunai

\section{Milenial dan Teknologi}

Milenial merupakan generasi yang lahir dari tahun 1980 ke atas (Pyöriä et al 2017), pada generasi ini teknologi mengalami perkembangan yang cukup pesat, oleh karena itu menurut laporan yang disajikan dalam oleh Ericsson perkembangan teknologi akan sejalan dengan gaya hidup para generasi milenial, mereka cenderung menggunakan fasilitas online berbasis teknologi dibandingkan generasi sebelumnya Moore (2012), dan Oliveira et al (2018) mengungkapkan bahwa generasi milenial sangat dominan dalam penggunaan teknologi sebagai sarana yang dapat mendukung aktivitas kehidupan sehari-hari mereka, baik sebagai sarana yang mendukung pekerjaan, sosial, pendidikan maupun sebagai hiburan.

Pertumbuhan masyarakat milenial di Indonesia berdasarkan laporan yang disajikan oleh (Budiati et al 2018) 33,75\% terdiri dari generasi milenial yang juga menjadi sumber utama dalam perubahan teknologi yang ada. Sejalan dengan meningkatnya konsumsi milenial terhadap penggunaan teknologi juga memicu perubahan terhadap penggunaan teknologi dalam industri keuangan (fintech), hal tersebut bertujuan untuk mendukung adanya kenyamanan, kemudahan, kecepatan dan biaya layanan yang lebih efisien (Tan et al 2019).Hal ini dapat digambarkan oleh model hipotesis hubungan antara variabel manifes sebagai berikut:

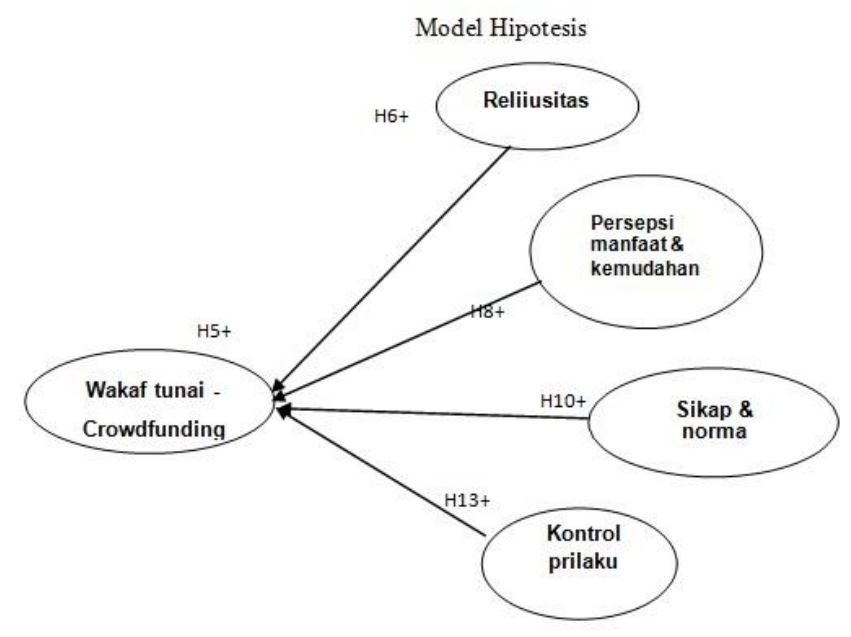




\section{METODOLOGI}

Untuk mengetahui tingkat validitas pada model, pengukuran dilakukan berdasarkan inovasi pada literature-literatur sebelumnya yang berkaitan dengan variabel yang digunakan (religiusitas, TAM dan TPB). Penelitian ini menggunakan data primer yang melibatkan 100 responden dengan metode penyebaran kuesioner. Adapun pengukuran penilaian yang digunakan ialah didasarkan pada pengukuran skala likert.

Responden terdiri dari beberapa akademisi dan pelajar ilmu ekonomi Islam dengan kriteria usia yang berkisar antara generasi milenial dan Z yakni 20-32 tahun. Sedangkan pembuatan model pada penelitian ini ialah didasarkan pada teori TAM dan TPB yang dinilai dapat menggambarkan penerimaan dan penggunaan suatu teknologi (Thaker et al 2019). Pengujian pada pengukuran model tersebut menggunakan analisis PLS (Partial Least Squares), dimana PLS dinilai dapat mengukur kecocokan antara konstruk yang terdapat dalam model (Tenenhaus et al 2005).

\section{HASIL DAN PEMBAHASAN}

\section{Hasil Analisis Data}

Berdasarkan kuesioner yang ada, jenis kelamin responden di dominasi oleh perempuan dengan persentase 58\%, laki-laki 42\%. Usia responden rata-rata terdiri dari umur 20-25 dengan persentase $85 \%$, dengan rata-rata tingkat pendidikan sarjana (S1).

\section{Assessment of Measurement Model}

Pengukuran model dapat dilakukan dengan Mengukur tingkat relibilitas dan validitas pada model dengan melihat nilai alpha dan nilai CR (Composite Ratio) untuk mengetahui apakah indikator yang digunakan sudah dapat menggambarkan variabel yang ada dengan batasan nilai 0,7 . Sehingga apabila nilai $<0,7$ maka dapat disimpulkan bahwa indikator pada variabel tidak reliabel. 
Tabel 1 Assessment of the Measurement Model

\begin{tabular}{|c|c|c|c|c|}
\hline Construct & Item & $\begin{array}{l}\text { Croncbach's } \\
\text { Alpha }\end{array}$ & $\begin{array}{l}\text { Composite } \\
\text { Ratio }\end{array}$ & AVE \\
\hline Crowdfunding- & WT1 & & & \\
\hline \multirow[t]{4}{*}{ wakaf tunai } & WT2 & & & \\
\hline & WT3 & 0,758 & 0,840 & 0,520 \\
\hline & CW1 & & & \\
\hline & CW2 & & & \\
\hline \multirow[t]{2}{*}{ Religiusitas } & R1 & & & \\
\hline & $\mathrm{R} 2$ & 0,651 & 0,840 & 0,726 \\
\hline \multicolumn{5}{|l|}{ Persepsi } \\
\hline manfaat dan & PU & 0,853 & 0,924 & 0,858 \\
\hline kemudahan & PE & & & \\
\hline Sikap dan & S1 & & & \\
\hline norma & PS1 & 0,595 & 0,779 & 0,543 \\
\hline subjektif & PS2 & & & \\
\hline Kontrol & KP1 & 0,765 & 0,894 & 0,809 \\
\hline prilaku & KP2 & & & \\
\hline
\end{tabular}

Tabel di atas merupakan tabel yang digunakan untuk mengukur tingkat reliabilitas dan validitas data. Berdasarkan tabel diatas, tingkat reliabilitas tertinggi diperoleh oleh variabel perspesi manfaat dan kemudahan dengan nilai cronbach's alpha sebesar 0,835>0,7 dan $\mathrm{Cr}$ $0,923>0,7$. Sedangkan nilai terendah diperoleh oleh variabel sikap dan norma subjektif besaran cronbach's alpha 0,595<0,7 dan Cr 0,777.

Hal tersebut menunjukkan bahwa indikator pada sikap dan norma subjektivitas dapat digunakan namun tidak benar-benar dapat merepresentasikan variabel yang ada. Selanjutnya tingkat validitas dapat diketahui melalui nilai AVE, dimana nilai validitas tertinggi juga berada pada variabel persepsi manfaat dan kemudahan. Hal ini menunjukkan bahwa indikator yang 
digunakan sudah benar-benar dapat menggambarkan variabel berdasarkan kepercayaan dan keabsahan data yang ada, sehingga dapat disimpulkan bahwa rata-rata responden setuju dengan adanya manfaat dan kemudahan yang ada pada inovasi wakaf tunai berbasis crowdfunding.

\section{Assessment of Structural Model}

Menurut Rumayah (2015) nilai pada $\mathrm{R}^{2}$ dapat digunakan untuk mengamati kesesuaian pada model, hal ini sejalan dengan pendapat yang dikemukakan oleh Ryu (2018) bahwa terdapat tiga faktor untuk dapat mengukur reliabilitas dan validitas, yaitu penilaian terhadap konten, konvergen, dan diskriminan. Pertama, validitas isi mengacu terhadap kepahaman dari kelompok yang digunakan. Ini dinilai dengan melihat proses dari item skala yang dihasilkan, dengan menguji konsistensi antara item pengukuran dan literatur yang masih ada.

Kedua, validitas konvergen dinilai menggunakan Cronbach's alpha, reliabilitas komposit dan varians rata-rata yang diekstraksi (AVE) untuk setiap konstruk (Barclayetal., 1995). Jika nilai lebih tinggi dari 0,5 , maka hal tersebut dinilai dapat mendukung validitas konvergen. Berdasarkan nilai rata AVE yang ada pada tabel bernilai $>0,5$. Selain itu menurutnya nilai pada setiap variabel laten harus lebih besar dari nilai $\mathrm{R}^{2}$. Sedangkan ingkat pengukuran validitas secara diskriminana dapat digambarkan oleh tabel II.

Tabel 2 Cross Loading

\begin{tabular}{llllll}
\hline item & $\begin{array}{l}\text { Crowdfunding- } \\
\text { wakaf tunai }\end{array}$ & Religiusitas & $\begin{array}{l}\text { Persepsi manfaat } \\
\text { dan kemudahan }\end{array}$ & $\begin{array}{l}\text { Sikap } \\
\text { norma } \\
\text { subjektif }\end{array}$ & $\begin{array}{l}\text { Kontrol } \\
\text { prilaku }\end{array}$ \\
\hline $\mathrm{T} 1$ & 0,721 & 0.574 & 0,539 & 0,411 & 0,337 \\
\hline $\mathrm{T} 2$ & 0,501 & 0,323 & 0,418 & 0,381 & 0,226 \\
\hline $\mathrm{T} 3$ & 0,685 & 0,492 & 0,479 & 0,465 & 0,278 \\
\hline $\mathrm{W} 1$ & 0,766 & 0,519 & 0,510 & 0,558 & 0,453 \\
\hline $\mathrm{W} 2$ & 0,878 & 0,648 & 0,717 & 0,649 & 0,516 \\
\hline $\mathrm{R} 1$ & 0,406 & 0,757 & 0,354 & 0,306 & 0,106 \\
\hline $\mathrm{R} 2$ & 0,755 & 0,938 & 0,676 & 0,599 & 0,391 \\
\hline $\mathrm{U}$ & 0,672 & 0,544 & 0,916 & 0,637 & 0,439 \\
\hline $\mathrm{E}$ & 0,178 & 0,645 & 0,936 & 0,755 & 0,494 \\
\hline
\end{tabular}


Jurnal Al-Iqtishad Edisi 17 Volume 1 Tahun 2021

Ahwal

\begin{tabular}{llllll}
\hline S1 & 0,661 & 0,555 & 0,754 & 0,850 & 0,480 \\
\hline PS1 & 0,455 & 0,362 & 0,429 & 0,695 & 0,391 \\
\hline PS2 & 0,345 & 0,266 & 0,386 & 0,647 & 0,417 \\
\hline KP1 & 0,430 & 0,270 & 0,477 & 0,506 & 0,896 \\
\hline KP2 & 0,505 & 0,330 & 0,433 & 0,539 & 0,904 \\
\hline
\end{tabular}

Berdasarkaan tabel tersebut dapat diketahui bahwa rata-rata nilai variabel laten pada setiap variabel lebih tinggi dibandingkan nilai pada variabel laten lainnya. Sehingga kevalidan variabel dapat digolongkan sebagai variabel yang andal.

Berikut merupakan model yang dihasilkan setelah dilakukan uji PLS pada model hipotesis sebelumnya.

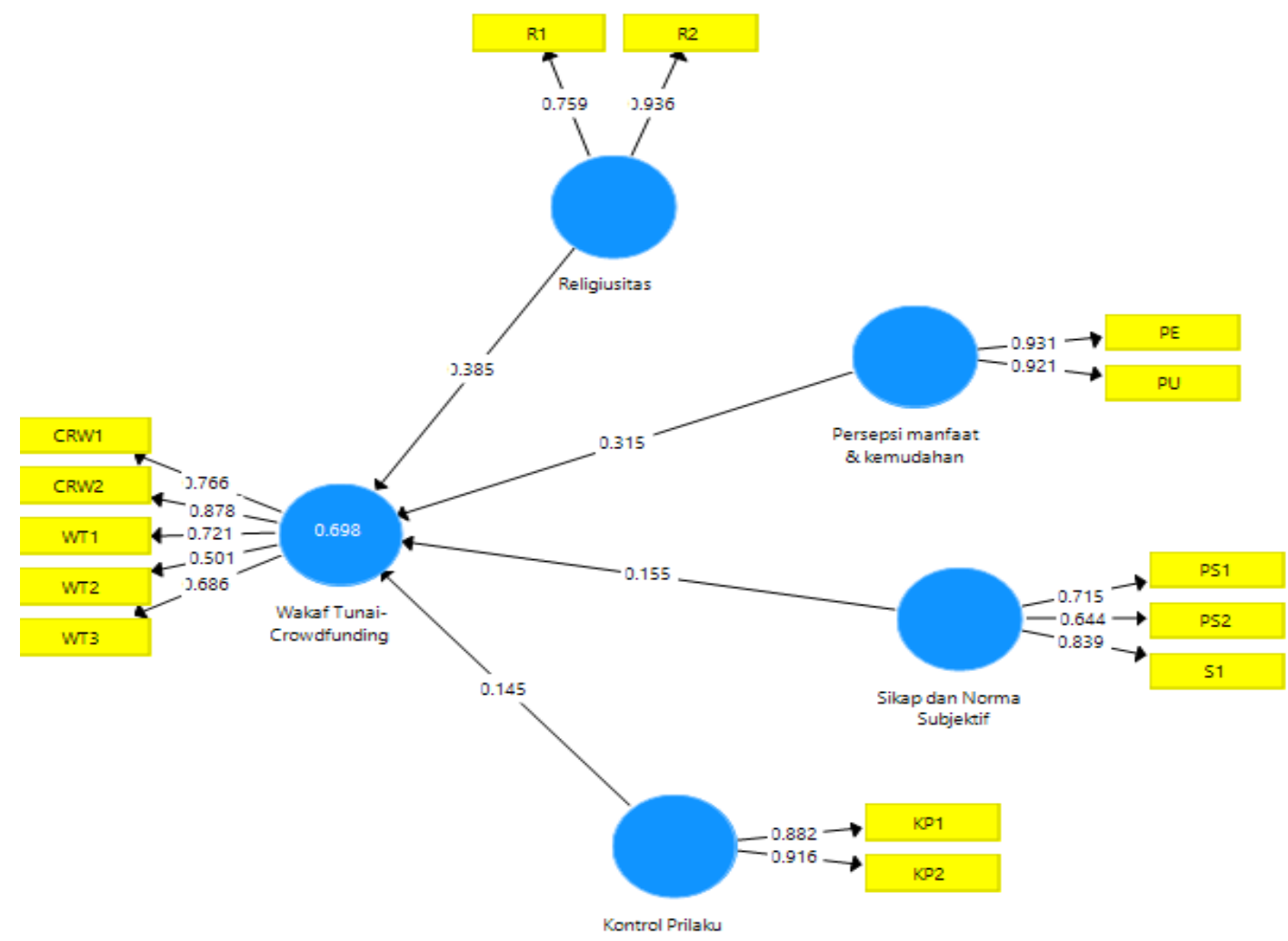

Gambar 2 Wakaf tunai berbasis crowdfunding: persepsi milenial dan $\mathrm{Z}$ model 
Berdasarkan gambar pada model tersebut maka dapat diketahui bahwa $\mathrm{R}^{2}$ sebesar 0,698\%, hal itu menunjukkan bahwa 69,8\% dari varian persepsi wakaf tunai berbasis crowdfunding menurut generasi milenial dan $\mathrm{Z}$ dapat dijelaskan oleh model tersebut. Thaker et al (2019) mengungkapkan bahwa batas minimal nilai $\mathrm{R}^{2}$ ialah $10 \%$. Selanjutnya untuk menilai signifikasi jalur dari model structural dilakukan penilaian pada path coefficients, dimana nilai religiusitas menjadi faktor tertinggi terkait dengan penggunaan wakaf tunai berbasis crowdfunding $(\beta=0,385, \mathrm{p}<0,01)$, variabel manfaat dan kemudahan juga memiliki keterkaitan yang kuat dalam mempengaruhi penggunaan crowdfunding $(\beta=0,315, \mathrm{p}<0,01)$.

Sedangkan pada variabel kontrol perilaku meski memiliki keterkaitan dan mempengaruhi penggunaan crowdfunding pada wakaf tunai namun hubungan tersebut sedikit lemah $(\beta=0,145, p<0,01)$, hal ini tidak berbeda jauh dengan variabel sikap \& norma subjektif ( $\beta=0,155, p<0,01)$. Sehingga dapat disimpulkan bahwa H6, H7, H8, H9 diterima dan memiliki pengaruh yang sangat kuat dalam penerimaan dan penggunaan teknologi crowdfunding. Sedangkan H1, H2, H3, H4, H5, H10, H11, H12, H13, H14, diterima dan dinilai memberikan pengaruh meski dalam skala yang relatif lebih rendah. Hal ini juga di dasarkan pada nilai CR dan AVE yang rata-rata cukup andal.

\section{PEMBAHASAN}

Dari model PLS yang ditunjukkan oleh gambar II dapat disimpulkan bahwa sebanyak 69\% responden sudah mengetahui tentang mekanisme wakaf tunai, selain itu responden juga setuju bahwa terdapat motif religiusitas dalam menunaikan wakaf tunai berbasis crowdfunding dengan mempertimbangkan kemudahan serta efisiensi dalam berbuat amal kebaikan, akan tetapi tingkat penggunaan crowdfunding sebagai sarana pembayaran wakaf tunai masih belum maksimal digunakan oleh para generasi milenial dan $\mathrm{Z}$.

Oleh karena itu berdasarkan temuan serta solusi yang disarankan oleh Nadya et al (2018) yang menunjukkan sejumlah masalah waqaf tunai di Indonesia, yang diantaranya ialah sosialisasi terkait pengetahuan masyarakat akan wakaf tunai. Adanya sosialiasi yang dilakukan oleh pihak BWI melalui program goes to campus turut andil dalam memberikan pengaruh terhadap peningkatan pengetahuan genarasi $\mathrm{Y}$ dan $\mathrm{Z}$.

Selain itu adanya faktor religiusitas yang dinilai dapat mendukung adanya kesetujuan responden dalam mengalokasikan dananya pada wakaf tunai, menurut beberapa penelitian juga 
menjadi salah satu motif utama seseorang dalam menunaikan wakaf (Noor et al 2015; Rizal \& Amin, 2017; Syafira et al 2020). Hal ini sangat dipengaruhi oleh adanya beberapa perintah dan anjuran tentang pentingnya menfakahkan harta di jalan Allah, yang salah satunya adalah wakaf sepeti Dalam firmanAllah berikut:

Artinya: "kamu sekali-kali tidak sampai kepada kebajikan (yang sempurna), sebelum kaтu menafkahkan sebagian harta yang kaтu cintai. Dan apa saja yang kamu nafkahkan maka sesungguhnya Allah mengetahuinya" (QS. Al-Imran: 92).

Sejalan dengan ayat di atas Rasulullah Saw bersabda: "Ketika anak adam mati, maka terputuslah amalnya kecuali tiga perkara; sedekah jariyah, ilmu yang bermanfaat, dan anak shaleh yang mendoakannya" (HR. Muslim)

Berdasarkan dua landasan tersebut, akan sangat memungkinkan apabila motif religiusitas menjadi motif utama seorang muslim dalam menunaikan wakaf baik tunai maupun tidak, dengan melihat adanya kecenderungan kontrol perilaku yang disebabkan oleh faktor religiusitas.

Selanjutnya adanya kemudahan yang ditawarkan oleh fintech yang digunakan berdasarkan respon responden, dapat mempengaruhi motivasi mereka dalam menunaikan wakaf tunai berbasis crowdfunding, yang dinilai lebih efektif serta efisien bagi generasi $\mathrm{Y}$ dan $\mathrm{Z}$, hal serupa juga ditunjukkan oleh Jalil et al (2019) dimana responden wakaf tunai di Malaysia ratarata juga lebih memilih menggunakan pembayaran online dibnadingkan offline.

Niswah et al (2019)juga melihat kecenderuangan penggunaan jenis fintech oleh para donor menemukan bahwa jenis fintech yang secara fleksibel menyediakan banyak penawaran seperti Go-Pay lebih dominan digunakan sebagai sarana pemanfaatan donasi amal dibandikangkan jenis fintech lainnya. Oleh karena itu para waqif harus menyesuaikan intensitas penggunaan fintech yang digunakan oleh para kaum milenial dan $\mathrm{Z}$ terhadap kampanye crowdfunding yang akan digunakan, sehingga penggunaan metode crowdfunding dalam memaksimalkan wakaf tunai dapat dimanfaatkan secara maksimal.

\section{PENUTUP}

Berdasarkan pengukuran dan pengujian yang sudah dilakukan pada model hipotesis yang ada, dapat disimpulkan bahwa kesadaran generasi $\mathrm{Y}$ dan $\mathrm{Z}$ akan pentingnya wakaf sebagai investasi dunia akhirat semakin meningkat. Hal ini ditunjukkan dengan persepsi para milenial 
dan generasi $\mathrm{Z}$ yang menilai bahwa faktor religiusitas memberikan pengaruh terhadap penggunaan wakaf tunai berbasis crowdfunding.

Hal tersebut juga didukung oleh adanya faktor manfaat dan kemudahan yang terdapat dalam wakaf tunai, dengan model yang lebih efisien untuk dijadikan sebagai pembiayaan ataupun investasi yang hasilnya dapat digunakan untuk kesejahteraan umat secara berkelanjutan. Oleh karena itu dengan adanya inovasi pada fintech yang dapat dimanfaatkan oleh lembaga keuangan Islam baik yang bersifat komersial maupun filantropi dapat mengoptimalkan potensi dari instrumen-instrumen keuangan Islam, terutama mengoptimalkan potensi wakaf, baik yang bergerak maupun tidak bergerak dan secara signifikan turut serta dalam mensejahterakan umat.

Penelitian ini memiliki keterbatasan pada sampel yang hanya terdiri dari akademisi dengan rataan pendidikan tentang pengetahuan ekonomi Islam, sehingga hal tersebut mungkin tidak dapat benar-benar merepresentasikan persepsi para generasi milenial dan $\mathrm{Z}$ secara keseluruhan. Oleh karena itu untuk penelitian selanjutnya penulis menyarankan untuk memperluas jangkauan kriteria sampel yang digunakan..

Setelah adanya gambaran terkait perspesi dan efektivitas sosialisasi wakaf kepada masyarakat khususnya tentang wakaf tunai. Berdasarkan hasil dan penelitian sebelumnya Peneliti menyarankan adanya penggalakan cash waqf berbasis crowdfunding, karena sebagaimana yang kita ketahui saat ini penggunaan crowdfunding sebagai salah satu sarana pengumpulan wakaf tunai masih belum optimal.

Hal ini diperlukan untuk mengoptimalkan potensi wakaf tunai dan antusiasme masyarakat terhadap keberadaan wakaf tunai dengan tidak mengabaikan saran saran penelitian sebelumnya terutama terkait kualitas nadzir. Selain itu penggunaan crwodfunding sebagai platform bagi wakaf tunai juga harus disertai dengan model pengelolaan yang jelas. 


\section{DAFTAR PUSTAKA}

Agreement, G., \& Union, E. (2020). Crowdfunding As a Novel Financial Tool for District. 768936.

Ajzen, I. (1987). Attitudes, traits and actions: dispositional prediction of behaviour in social pshychology. Advances in Experimental Social Psychology, 20, 63.

Ajzen, I. (1991). The theory of planned behavior. ORGANIZATIONAL BEHAVIOR AND HUMAN DECISION PROCESSES, 50, 179-21. https://doi.org/10.15288/jsad.2011.72.322

Ajzen, I. (2012). The theory of planned behavior. Handbook of Theories of Social Psychology: Volume 1, January 2012, 438-459. https://doi.org/10.4135/9781446249215.n22

Akhtar, S., Irfan, M., Sarwar, A., Asma, \& Rashid, Q. U. A. (2019). Factors influencing individuals' intention to adopt mobile banking in China and Pakistan: The moderating role of cultural values. Journal of Public Affairs, 19(1), 1-15. https://doi.org/10.1002/pa.1884

Alam, S. S., Mohd, R., \& Hisham, B. (2011). Is religiosity an important determinant on Muslim consumer behaviour in Malaysia? Journal of Islamic Marketing, 2(1), 83-96. https://doi.org/10.1108/17590831111115268

Amaliah, I., Aspiranti, T., \& Purnamasari, P. (2015). The Impact of the Values of Islamic Religiosity to Islamic Job Satisfaction in Tasikmalaya West Java, Indonesia, Industrial Centre. Procedia - Social and Behavioral Sciences, 211(September), 984-991. https://doi.org/10.1016/j.sbspro.2015.11.131

Au-Yong-Oliveira, M., Gonçalves, R., Martins, J., \& Branco, F. (2018). The social impact of technology on millennials and consequences for higher education and leadership. Telematics and Informatics, 35(4), 954-963. https://doi.org/10.1016/j.tele.2017.10.007

Budiati, I., Susianto, Y., Adi, W. P., Ayuni, S., Reagan, H. A., Larasaty, P., Setiyawati, N., Pratiwi, A. I., \& Saputri, V. G. (2018). Profil Generasi Milenial Indonesia. 1-153. www.freepik.com

Che Hassan, S. N. A., \& Rahman, A. A. (2018). The Potential of Cash Waqf in the Socio-economic Development of Society in Kelantan . New Developments in Islamic Economics, 
67-82. https://doi.org/10.1108/978-1-78756-283-720181005

Che Zuina Ismail, Syafini Muda, \& Nor Jawanees Ahmad Hanafiah. (2014). Challenges and Prospects of Cash Waqf Development in Malaysia. Journal of Basic and Applied Scientific Research, 4(2), 340-348.

Davis, F D. (1985). A technology acceptance model for empirically testing new end-user information systems: Theory and results. Management, Ph.D.(January 1985), 291. https://doi.org/oclc/56932490

Davis, Fred D. (1989). Perceived usefulness, perceived ease of use, and user acceptance of information technology. MIS Quarterly: Management Information Systems, 13(3), 319-339. https://doi.org/10.2307/249008

Eastman, J. K., Iyer, R., Liao-Troth, S., Williams, D. F., \& Griffin, M. (2014). The role of involvement on millennials' mobile technology behaviors: The moderating impact of status consumption, innovation, and opinion leadership. Journal of Marketing Theory and Practice, 22(4), 455-470. https://doi.org/10.2753/MTP1069-6679220407

Eid, R., \& El-Gohary, H. (2015). The role of Islamic religiosity on the relationship between perceived value and tourist satisfaction. Tourism Management, 46, 477-488. https://doi.org/10.1016/j.tourman.2014.08.003

Fallis, A. . (2013). Factors Influencing Willingness To Contribute In Cash Waqf: Case Of South Tangerang, Indonesia. Journal of Chemical Information and Modeling, 53(9), 16891699. https://doi.org/10.1017/CBO9781107415324.004

Jalil, M. I. A., Pitchay, A. A., \& Yahya, S. (2019). Cash Waqf and Preferred Method of Payment: Case of Malaysia Using an AHP Approach. Revitalization of Waqf for Socio-Economic Development, Volume II, January 2019, 187-206. https://doi.org/10.1007/978-3-030-18449$0 \_10$

Johan, Z. J., \& Putit, L. (2016). Conceptualizing the Influences of Knowledge and Religiosity on Islamic Credit Card Compliance. Procedia Economics and Finance, 37(16), 480487. https://doi.org/10.1016/s2212-5671(16)30155-1 
Kachkar, O. A. (2017). Towards the establishment of cash waqf microfinance fund for refugees. ISRA International Journal of Islamic Finance, 9(1), 81-86. https://doi.org/10.1108/IJIF-07-2017-007

Khamis, S. R., \& Che Mohd Salleh, M. (2018). Study on the Efficiency of Cash Waqf Management in Malaysia. Journal of Islamic Monetary Economics and Finance, 4(1), 61-84. https://doi.org/10.21098/jimf.v4i1.732

Mcauley, D., \& Weiner, S. (2015). The Millennial Generation and the Future of Finance: A Different Kind of Trust. June.

Mohd Thas Thaker, M. A. Bin, Allah Pitchay, A. Bin, Mohd Thas Thaker, H. Bin, \& Amin, M. F. Bin. (2019). Factors influencing consumers' adoption of Islamic mobile banking services in Malaysia: An approach of partial least squares (PLS). Journal of Islamic Marketing, 10(4), 1037-1056. https://doi.org/10.1108/JIMA-04-2018-0065

Mohd Thas Thaker, M. A. Bin, Amin, M. F. Bin, Mohd Thas Thaker, H. Bin, \& Allah Pitchay, A. Bin. (2019). What keeps Islamic mobile banking customers loyal? Journal of Islamic Marketing, 10(2), 525-542. https://doi.org/10.1108/JIMA-08-2017-0090

Mohd Thas Thaker, M. A., Mohd Thas Thaker, H., \& Allah Pitchay, A. (2018). Modeling crowdfunders' behavioral intention to adopt the crowdfunding-waqf model (CWM) in Malaysia: The theory of the technology acceptance model. International Journal of Islamic and Middle Eastern Finance and Management, 11(2), 231-249. https://doi.org/10.1108/IMEFM-062017-0157

Mollick, E. (2014). The dynamics of crowdfunding: An exploratory study. Journal of Business Venturing, 29(1), 1-16. https://doi.org/10.1016/j.jbusvent.2013.06.005

Moore, M. (2012). Interactive media usage among millennial consumers. Journal of Consumer Marketing, 29(6), 436-444. https://doi.org/10.1108/07363761211259241

Nadya, P., Alwyni, F. A., \& Iqbal, M. (2018). Strategy of Optimalization Cash Waqf In Indonesia. Jurnal Syarikah P-ISSN, 4(2), 108-121. https://doi.org/10.30997/jsei.v4i2.1501

Niswah, F. M., Mutmainah, L., \& Legowati, D. A. (2019). Muslim Millennial'S 
Intention of Donating for Charity Using Fintech Platform. Journal of Islamic Monetary Economics and Finance, 5(3), 623-644. https://doi.org/10.21098/jimf.v5i3.1080

Noor, A. H. B. M., Isa, N. A. M., Irpan, H. M., Bahrom, H. Bin, Salleh, A. B. M., \& Ridzuan, A. R. Bin. (2015). Characteristic Affecting Charitable Donations Behavior: Empirical Evidence from Malaysia. Procedia Economics and Finance, 31(15), 563-572. https://doi.org/10.1016/s2212-5671(15)01202-2

Personal, M., \& Archive, R. (2013). Munich Personal RePEc Archive The Implication of Cash Waqf in the Society. 44605.

Pyöriä, P., Ojala, S., Saari, T., \& Järvinen, K. M. (2017). The millennial generation: A new breed of labour? SAGE Open, 7(1). https://doi.org/10.1177/2158244017697158

Ramdhani, N. (2016). Penyusunan Alat Pengukur Berbasis Theory of Planned Behavior. Buletin Psikologi, 19(2), 55-69. https://doi.org/10.22146/bpsi.11557

Rijanto, A. (2018). Donation-based crowdfunding as corporate social responsibility activities and financing. Journal of General Management, 43(2), 79-88. https://doi.org/10.1177/0306307017748125

Rizal, H., \& Amin, H. (2017). Perceived ihsan, Islamic egalitarianism and Islamic religiosity towards charitable giving of cash waqf. Journal of Islamic Marketing, 8(4), 669-685. https://doi.org/10.1108/JIMA-05-2015-0037

Ryu, H. S. (2018). What makes users willing or hesitant to use Fintech?: the moderating effect of user type. Industrial Management and Data Systems, 118(3), 541-569. https://doi.org/10.1108/IMDS-07-2017-0325

Shaikh, S. A., Ismail, A. G., \& Mohd Shafiai, M. H. (2017). Application of waqf for social and development finance. ISRA International Journal of Islamic Finance, 9(1), 5-14. https://doi.org/10.1108/IJIF-07-2017-002

Shneor, R., \& Munim, Z. H. (2019). Reward crowdfunding contribution as planned behaviour: An extended framework. Journal of Business Research, 103(June), 56-70. https://doi.org/10.1016/j.jbusres.2019.06.013 
Sulaiman, M., \& Alhaji Zakari, M. (2019). Financial sustainability of state waqf institutions (SWIs) in Malaysia. Journal of Islamic Accounting and Business Research, 10(2), 236-258. https://doi.org/10.1108/JIABR-05-2016-0054

Syafira, F. N., Ratnasari, R. T., \& Ismail, S. (2020). the Effect of Religiosity and Trust on Intention To Pay in Ziswaf Collection Through Digital Payments. Jurnal Ekonomi Dan Bisnis Islam (Journal of Islamic Economics and Business), 6(1), 98. https://doi.org/10.20473/jebis.v6i1.17293

Tan, J. D., Purba, J. T., \& Widjaya, A. E. (2019). Financial Technology as an Innovation Strategy for Digital Payment Services in the Millenial Generation. 292(Agc), 364373. https://doi.org/10.2991/agc-18.2019.58

Tenenhaus, M., Vinzi, V. E., Chatelin, Y. M., \& Lauro, C. (2005). PLS path modeling. Computational Statistics and Data Analysis, 48(1), 159-205. https://doi.org/10.1016/j.csda.2004.03.005

Thoarlim, A., Rahman, M. A., \& Yanya, A. (2017). Cash Waqf in Bangladesh and the Need for Innovative Approach towards Awqaf: Lessons from Selected Countries. International Journal of Academic Research in Business and Social Sciences, 7(4), 151-169. https://doi.org/10.6007/ijarbss/v7-i4/2795

Zacharis, N. Z. (2012). Predicting college students' acceptance of podcasting as a learning tool. Interactive Technology and Smart Education, 9(3), 171-183. https://doi.org/10.1108/17415651211258281

Zamani-Farahani, H., \& Musa, G. (2012). The relationship between Islamic religiosity and residents' perceptions of socio-cultural impacts of tourism in Iran: Case studies of Sare'in and Masooleh. Tourism Management, 33(4), 802-814. https://doi.org/10.1016/j.tourman.2011.09.003 